\title{
BIOLOGICAL ASPECTS OF TWO PREDATORS AS AFFECTED BY FEEDING ON TWO APHID SPECIES, APHIS GOSSYPII GLOVER AND HYALOPTERUS PRUNI (GEOFFROY) UNDER LABORATORY CONDITIONS
}

\author{
SALEH, A.A.A. ${ }^{1}$ and SH. A.M. ALI ${ }^{2}$ \\ 1. Biological Control Research Dept., Plant Prot. Res. Institute, ARC, Dokki, Giza, \\ Egypt. \\ 2. Piercing \& Sucking Insect Research Dept. Plant Prot. Res. Institute, ARC, Giza, \\ Egypt
}

(Manuscript received 7 March 2012)

\begin{abstract}
Laboratory experiments were carried out to study certain biological parameters of the two predatory species coccinella undecimpunctata L. and Chrysoperla carnea (Stephens) by rearing confinement on Aphis gossypii and Hyalopterus pruni. The total developmental time from egg hatching to adult eclosion were 18.85 \pm 0.26 and $21.60 \pm 0.2$ days for $C$. undecimpunctata, while it was $26.16 \pm 0.56$ and $24.42 \pm 0.29$ days for Ch. carnea when fed on $A$. gossypii and $H$. pruni, respectively. Based on statistical analysis, the total developmental time showed significant difference between the two aphid species. The total consumption rate per $C$. undecimpunctata larva from the two aphid species were $190.05 \pm$ 4.75 and $246.55 \pm 7.26$ aphids individuals and $172.45 \pm 6.24$ and $623.18 \pm 41.80$ Aphids individuals for Ch. carnea. When reared on $H$. pruni and $A$. gossypii, respectively. The average number of aphids consumed per larva for the two predatory species was also significantly different. There were a significant difference in longevity among females, longevity of males and the fecundity of their females of the two predators. The average numbers consumed from the two aphid $A$. gossypii and $H$. pruni during adult female of $C$. undecimpunctata were $3046.4 \pm 104.29$ and $3797 \pm$ 124.72 aphid individuals, while adult males consumed $2478.9 \pm$ 66.19 and $2947.5 \pm 95.08$ aphid individuals when fed on the two aphid species respectively. The average number of deposited eggs per $C$. undecimpunctata female was $181.1 \pm 5.97$ and $301.9 \pm 7.3$ eggs when reared on $A$. gossypii and $H$. pruni, respectively, while that was $327.73 \pm 31.19$ and $459.43 \pm 24.57$ eggs when $C h$. carnea females fed on $A$. gossypii and Hyalopterus pruni during larval instars, respectively. The statistical analysis showed that the aphid species have a highly significant effect on the female fecundity.
\end{abstract}

Key words: Biological characteristics, Coccinella undecimpunctata L. Chrysoperla carnea, Stephens Aphis gossypii, Glover Hyalopterus pruni(Geoffroy). 


\section{INTRODUCTION}

Aphids are considered as one of the most important pests due to their vary wide range of host plants in Egypt and in many parts of the world (Megahed 2000). Use of insecticides in controlling aphids have lead to several problems, not only increasing resistant strain of aphids to those chemicals but also induction of environmental pollution and disturbance of natural balance (El-Maghraby, 1993). The efficiency of the two predators, Coccinella undecimpunctata L. (Coleoptera: Coccinellidae) and Chrysoperla carnea (Stephens) (Neuroptera: Chrysopidae) as biological control agents have been studied in different parts of the world (Soares et. al.,2003 and Ali 2008). Several studies have been carried out in different parts of the world concerning the predation activity of many predator species such as, $C$. undecimpunctata and Ch. carnea. Among those who contributed much to these studies are (Abou Zeid et. al.,1978, Yuksel and Goemen 1992, Eraky and Nasser 1993 and El-Hag and Zaitoon 1996). The neuropteran predators Chrysoperla carnea and Ch. septempunctata Wesm. have attracted considerable attention as a biological agent to control important agricultural pests. Ch. septempunctata is one of the few species among the chrysopids which both its larvae and adults are predaceous (Abou-Bakr, 1989). Therefore, this investigation was out lined to study certain biological characteristics of the coccinellid predator, $C$. undecimpunctata and the neuropteran predator, Ch. carnea when reared on two aphid species Aphis gossypii Glover and Hyalopterus pruni (Geoffer) under laboratory conditions.

\section{MATERIALS AND METHODS}

Experiments were carried out at the laboratory of plant protection Sharkia branch under $27 \pm 1^{\circ} \mathrm{C}$ and $70 \pm 5.0 \%$ R.H. two aphid species, namely, Aphis gossypii and Hyalopterus pruni were used as preys for the two predators, Coccinella undecimpunctata and Chrysoperla carnea. The predators and the prey individuals were obtained from a maintained culture in the insectary also preys were collected directly from the field.

\section{A. Larva experiments}

Newly hatched predators larvae from two predators were put individually in a Petri - dish $(10 \mathrm{~cm}$. diameter) with a filter paper on its bottom. Twenty replicates from each were reared on two aphid species. Know surplus numbers of prey species were offered and the devoured individuals were replaced daily. Attacked prey 
individuals were counted and recorded daily throughout the periods of the larval instars.

\section{B. Adult experiments}

\section{Coccinell undecimpunctata}

After emergence from the pupae, each predator adults were sexed and then introduced singly into a Petri- dish. Known numbers of the two aphids were offered daily on a plant leaflet to each predator. Counting and removing the un- devoured aphids in each Petri- dish were practiced before introducing the new aphid individuals. After five days of emergence, copulation took place and the two sexes were immediately separated and kept singly in the dishes. Daily numbers of laid eggs per predator female during its ovipositional period was counted. In addition, the total number of eggs laid per predator female was estimated. The daily averages of prey consumption throughout adult longevities were calculated.

\section{Chrysoperla carnea}

When larva was transferred to the pupal stage in the spherical silky cocoon, date of cocoons formation was recorded. The cocoons were left until adult emergence. Newly emerged adults were sexed and each pair (one male and one female) was placed in a glass chimney. Each chimney was placed on a half Petri dish $(10 \mathrm{~cm}$ in diameter) and furnished with a moistened filter paper to provide humidity. A piece of cotton wool soaked with mixed solution of sugar and honey was placed inside the glass chimney as food for adults. Each chimney was covered with a piece of black cloth for encouraging females to oviposit. Pre oviposition, oviposition, post oviposition period, total number of eggs/female and longevity (female and male) were recorded.

\section{Data analysis}

Data for the developmental time of immature stages mortality, pre oviposition, oviposition, post oviposition periods, fecundity, male longevity, of the two predators reared on the tested aphid species were subjected for one way analysis of variance (ANOVA), and the means were separated using Dancan's Multiple Range Test (CoHort Software, 2004). 


\section{RESULTS AND DISCUSSION}

\section{Developmental time of immature stages}

\section{A. Coccinella undecimpunctata}

Data in Table (1) indicated that the incubation period of $C$. undecimpunctata are $4.75 \pm 0.12$ and $4.25 \pm 0.1$ days with significant difference among the two aphid species (A.gossypii and $H$. pruni). Considering the developmental time of larvae instars, the shortest developmental time was obtained when larvae reared on $A$. gossypii $(9.8 \pm 0.2$ days), while the longest time was recorded on $H$. pruni $(11.15 \pm$ 0.12 days). The developmental of larval instars showed a significant variation between the two aphid species (Table 1). From the tested aphid species, there were significant differences between developmental times of pupal stage. The longest time was observed with $H$. pruni, while the shortest time was obtained with $A$. gossypii. The total developmental time (from egg hatching to adult eclosion) ranged however, from $18.85 \pm 0.26$ days by rearing on $A$. gossypii to $21.60 \pm 0.29$ days by feeding on $H$. pruni with significantly differed. Mortality percentage from egg to adult ranged from $6.67 \%$ when reared on $H$. pruni to $10.0 \%$ with $A$. gossypi.

These findings agree with that of Abou Zeid et. al. (1978) reported that the incubation period of $C$. undecimpunctata was 2.7 days at $26-28^{\circ} \mathrm{C}$. Eraky and Nasser (1993) mentioned that this period for the same predator was 2.0 days at $30^{\circ} \mathrm{C}$. While El-Hag and Zaitoon (1996) found this period was 3.5 days at $25.0 \pm 2.0^{\circ} \mathrm{C}$ Ghanim and El-Adl (1987) found that larvae of C. undecimpunctata and C. vicina isis took 10.0 and 9.0 days when reared on both aphids, Rhopalosiphum maidis (Fitch) and $S$. avenae. When $C$. undecimpunctata reared on $R$. padi L., the larvae, pupae and complete immature stages averaged 7.0, 2.5 and 12.0 days at $30^{\circ} \mathrm{C}$ (Eraky and Nasser 1993). On the other hand Mohammed (1996) found that when $C$. undecimpunctata reared on Macrosiphum pisi (Harris) the larvae, pupae averaged 9.2 and 2.9 days at $26^{\circ} \mathrm{C}$. Mean while, Barakat (2005) reported that the incubation period, larva, pupa and total developmental period was lasted 5.7, 11.0, 7.6 and 24.3 days at $26.8^{\circ} \mathrm{C}$ when predator $\mathrm{C}$. undecimpunctata reared on $\mathrm{H}$. pruni, the fourth larval instar were consumed $15.7,50.4,48.2$ and 157.9 individuals respectively.

\section{B. Chrysoperla carnea}

Data in Table (2) showed that incubation period of Ch. carnea was $3.75 \pm$ 0.10 and $3.15 \pm 0.08$ days, when reared on $H$. pruni and $A$. gossypii, respectively. Considering the developmental time was obtained when larvae reared on $H$. pruni $(13.31 \pm 0.19$ days), while the longest time was recorded on $A$. gossypii (16.38 \pm 0.47 days). The developmental of larval instars showed a significant variation between the two aphid species (Table 2). From the tested aphid species, there was significant 
differences between developmental times of pupal stage. The longest time was observed with $H$. pruni, while the shortest time was obtained with $A$. gossypii. The total of immature stages were ranged from $24.42 \pm 0.29$ days by rearing on $H$. pruni to $26.16 \pm 0.56$ days by feeding on $A$. gossypii with significantly differed. Mortality percentage from egg to adult ranged from $5.0 \%$ to $10 \%$ when reared on $H$. pruni and $A$. gossypii, respectively. These findings agree with that of Atlihan et. al. (2001) in Turkey who mentioned that the total developmental period of $C$. carnea was 18.81 days when larvae were fed on $H$. pruni at means of $25 \pm 1{ }^{\circ} \mathrm{C}$ and $65 \pm 5 \%$ R.H. On the other hand, Balasubramani and Swamiappan (1994) found that the total developmental period of $C$. carnea was 20.15 days when the larvae were fed on $A$. gossypii infesting cotton. While, El-Maghraby et. al. (2008) found that the total developmental period of $C$. carnea was $19.38 \pm 0.23$ and $24.65 \pm 0.49$ days by rearing on $H$. pruni infested peach trees and $A$. gossypii infested navel orange trees, respectively. Under $28-29^{\circ} \mathrm{C}$ and $62 \pm 5 \%$ R.H.

\section{Feeding capacity}

\section{A. Coccinella undecimpunctata}

Data in Table (3) show the consumption period rate of C.undecimpunctata larval instars when reared on two aphid species. The average number of aphids consumed during the larva stage was $190.05 \pm 4.75$ individuals of $H$. pruni and $246.55 \pm 7.26$ individuals of $A$. gossypii. The average number of aphids consumed during fourth instar larvae were $103.55 \pm 3.77$ individuals of $H$. pruni and $125.25 \pm$ 5.17 individuals of $A$. gossypii. Consumed percentage differed between $50.80 \%$ on $A$. gossypii to $54.49 \%$ on $H$. pruni. The average number of consumed aphid per larvae was significantly different. On other hand Mohammed (1996) found that the average of the total consumption during the four larval stages of the predator $C$. undecimpunctata when reared on $M$. pisi was 27.7, 68.4, 123.9 and 144.0 individuals, respectively. While, Barakat (2005) mentioned that the average of the total consumption during four larval stages of the same predator was $15.7,50.4,48.2$ and 157.9 individuals, respectively when feeding on $H$. pruni.

\section{B. Chrysoperla carnea}

Data in Table (4) show the consumption period rate of Ch. carnea larval instars when reared on two aphid species. The average number of aphids consumed during the larval stage was $172.45 \pm 6.24$ individuals of $H$. pruni and $623.18 \pm 41.8$ individuals of $A$. gossypii . Consumed percentage differed between two aphid species, the third instar larvae was consumed a high percentage $46.26 \%$ of $H$. pruni and $59.13 \%$ of $A$. gossypii followed by second instar larvae $31.77 \%$ and $27.23 \%$ then the first instar larvae $21.97 \%$ and $13.64 \%$ of $A$. gossypii and $H$. pruni, respectively. These findings agree with that of Yuksel and Goemen 1992 in Turkey determined prey consumption of C. carnea in the laboratory at 25 and $30^{\circ} \mathrm{C}$ using $A$. gossypii $1^{\text {st }}$ larval 
instar predated on 53.6 and 60.3 individuals at 25 and $30^{\circ} \mathrm{C}$, respectively, $2^{\text {nd }}$ larval instar consumed 174.4 and 88.6 aphid and $3^{\text {rd }}$ larval instar fed on 724.4 and 506.7 preys respectively. On the other hand El-Maghraby et. al. 2008 found that the total larval stage of $C$. carnea consumed $169.53 \pm 6.45$ individuals of $H$. pruni and 617.57 \pm 5.29 individuals of $A$. gossypii infested navel orange, under $28-29^{\circ} \mathrm{C}$ and $62 \pm 5 \%$ R.H.

\section{Longevity and fecundity of adult stage}

\section{A. C. undecimpunctata}

Data in Table (5) and Figure (1) showed that the mean female longevity of this predator was significantly longer when fed on $H$. pruni, than when reared on $A$. gossypii. Also the mean male longevity of predator was significantly longer when fed on $H$. pruni and shortest on A. gossypii. The highest numbers of egg (301.9 eggs) were obtained when female fed on $H$. pruni followed by $A$. gossypii (181.1 eggs). The predator male adult consumed a total average 2478.9 when fed on $A$. gossypii and 2947.5 when reared on $H$. pruni, mean while the female consumed a total average of 3046.4 A. gossypii individuals, but it consumed a total average of $3797 \mathrm{H}$. pruni individuals Fig. (1). Eraky and Nasser (1993) noted that egg production per female of C. undecimpunctata was 142.33 at $26^{\circ} \mathrm{C}$. Whereas El-Hag and Zaitoon (1996) mentioned that oviposition and longevity periods for $C$. undecimpunctata females were 29.8 and 70.0 days. They found that number of eggs laid per female and daily mean of eggs were 370.5 and 142 eggs when reared on B. brassicae and R. padi, while Mohammed (1996) reported that oviposition and longevity period for the same predator females was 56.6 days with (481 eggs). The female consumed an average 4599.2 M. pisi individuals, during this period. On the other hand, Barakat (2005) found that oviposition and longevity period for this predator females was 43.5 days with (343.5 eggs) during this period. The female consumed an average $2531.7 \mathrm{H}$. pruni individuals while male consumed in average $2017.6 \mathrm{H}$. pruni individuals.

\section{B. Chrysoperla carnea}

Data in Table (6) showed that the mean female longevity of $C$. carnea was significantly longer when larvae fed on $H$. Pruni (46.96 days) than when reared on $A$. gossypii (39.28 days). Also the mean male longevity of predator was in significantly longer when fed on A. gossypii (10.14 days) than when reared on $H$. pruni (9.75 days). The highest numbers of egg (459.43 eggs) were obtained when larva fed on $H$. pruni followed by $A$. gossypii (327.73 eggs). 
Table 1. Mean duration of the developmental stages of predator C. undecimpuncatata reared on two aphid species under controlled conditions.

\begin{tabular}{|c|c|c|c|c|c|c|c|c|c|}
\hline \multirow{2}{*}{ Prey species } & \multirow{2}{*}{$\begin{array}{c}\text { Incubation } \\
\text { period }\end{array}$} & \multicolumn{5}{|c|}{ Larval instars } & \multirow{2}{*}{ Pupal stage } & \multirow{2}{*}{$\begin{array}{c}\text { Total of } \\
\text { immature } \\
\text { stages } \\
\end{array}$} & \multirow{2}{*}{$\begin{array}{c}\text { Mortality } \\
\%\end{array}$} \\
\hline & & $1^{\text {st }}$ & $2^{\text {nd }}$ & $3^{\text {rd }}$ & $4^{\text {th }}$ & Total & & & \\
\hline Aphis gossypii & $3.70 \pm 0.11 a$ & $1.9 \pm 0.07 \mathrm{~b}$ & $2.15 \pm 0.1 b$ & $2.45 \pm 0.11 a$ & $3.3 \pm 0.12 b$ & $9.8 \pm 0.2 b$ & $5.35 \pm 0.11 b$ & $18.85 \pm 0.26 b$ & 10.0 \\
\hline $\begin{array}{c}\text { Hyalopterus } \\
\text { pruni }\end{array}$ & $3.40 \pm 0.1 a$ & $2.2 \pm 0.09 a$ & $2.45 \pm 0.11 a$ & $2.7 \pm 0.12 \mathrm{a}$ & $3.8 \pm 0.1 a$ & $11.15 \pm 0.21 a$ & $7.05 \pm 0.12 \mathrm{a}$ & $21.60 \pm 0.29 a$ & 6.67 \\
\hline
\end{tabular}

Mean followed by the same letter in a column for each predator are not significantly different at the $1 \%$ level of probability ( Duncan's Multiple Rang Test).

Table 2. Duration (in days) (means + SD) of the developmental stages of Chrysoperla carnea (Stephens) reared on certain aphid species under controlled conditions.

\begin{tabular}{|c|c|c|c|c|c|c|c|c|}
\hline \multirow{2}{*}{ Prey species } & \multirow{2}{*}{$\begin{array}{c}\text { Incubation } \\
\text { period }\end{array}$} & \multicolumn{4}{|c|}{ Larval instars } & \multirow{2}{*}{ Pupal stage } & \multirow{2}{*}{$\begin{array}{c}\text { Total of } \\
\text { immature } \\
\text { stages } \\
\end{array}$} & \multirow{2}{*}{$\begin{array}{c}\text { Mortality } \\
\%\end{array}$} \\
\hline & & $1^{\text {st }}$ & $2^{\text {nd }}$ & $3^{\text {rd }}$ & Total & & & \\
\hline Aphis gossypii & $3.15 \pm 0.08 b$ & $4.5+0.13 a$ & $4.79 \pm 0.14 a$ & $7.0 \pm 0.34 a$ & $16.38+0.47 a$ & $6.61 \pm 0.26 \mathrm{~b}$ & $26.16 \pm 0.56 a$ & $10 \%$ \\
\hline $\begin{array}{c}\text { Hyalopterus } \\
\text { pruni }\end{array}$ & $3.75 \pm 0.10 \mathrm{a}$ & $4.79 \pm 0.14 a$ & $4.26 \pm 0.10 b$ & $4.26 \pm 0.10 \mathrm{~b}$ & $13.31 \pm 0.19 b$ & $7.31 \pm 0.15 a$ & $24.42 \pm 0.29 b$ & $5 \%$ \\
\hline
\end{tabular}

Mean followed by the same letter in a column for each predator are not significantly different at the $1 \%$ level of probability ( Duncan's Multiple Rang Test). 
Table 3. Mean numbers consumed (+SE) and percentage from different aphid species during larval instars of predator C. undecimpunctata under controlled conditions.

\begin{tabular}{|c|c|c|c|c|c|c|c|c|c|}
\hline \multirow{3}{*}{ Prey species } & \multicolumn{8}{|c|}{ Larval instars } & \multirow{3}{*}{ Total } \\
\hline & \multicolumn{2}{|c|}{$1^{\text {st }}$} & \multicolumn{2}{|c|}{$2^{\text {nd }}$} & \multicolumn{2}{|c|}{$3^{\text {rd }}$} & \multicolumn{2}{|c|}{$4^{\text {th }}$} & \\
\hline & No. & $\%$ & No. & $\%$ & No. & $\%$ & No. & $\%$ & \\
\hline H. prunii & $11.05 \pm 0.49 b$ & 5.81 & $20.5 \pm 1.06 \mathrm{~b}$ & 10.79 & $54.95 \pm 2.31 b$ & 28.91 & $103.55+3.77 b$ & 54.49 & $190.05 \pm 4.75 b$ \\
\hline A. gossypii & $14.20 \pm 0.77 a$ & 5.76 & $38.75 \pm 2.49 a$ & 15.72 & $68.35 \pm 1.63 a$ & 27.72 & $125.25 \pm 5.17 a$ & 50.80 & $246.55 \pm 7.26 a$ \\
\hline
\end{tabular}

Mean followed by the same letter in a column for each predator are not significantly different at the $1 \%$ level of probability (Duncan's Multiple Rang Test).

Table 4. Mean numbers consumed (+SD) and percentage from different aphid species during larval instars of Chrysoperla carnea (Stephens) under controlled conditions.

\begin{tabular}{|c|c|c|c|c|c|c|c|}
\hline \multirow{3}{*}{ Prey species } & \multicolumn{6}{|c|}{ Larval instars } & \multirow{3}{*}{$\begin{array}{c}\text { Total } \\
\text { Mean } \pm \text { SD }\end{array}$} \\
\hline & \multicolumn{2}{|c|}{$1^{\text {st }}$} & \multicolumn{2}{|c|}{$2^{\text {nd }}$} & \multicolumn{2}{|c|}{$3^{\text {rd }}$} & \\
\hline & Mean \pm SD & $\%$ & Mean \pm SD & $\%$ & Mean \pm SD & $\%$ & \\
\hline Hyalopterus pruni & $37.89 \pm 1.95 b$ & 21.97 & $54.78 \pm 3.19 b$ & 31.77 & $79.78 \pm 3.68 b$ & 46.26 & $172.45+6.24 b$ \\
\hline Aphis gossypii & $85.0 \pm 3.83 a$ & 13.64 & $169.68 \pm 4.95 a$ & 27.23 & $368.5 \pm 37.56 a$ & 59.13 & $623.18 \pm 41.80 a$ \\
\hline
\end{tabular}

Mean followed by the same letter in a column for each predator are not significantly different at the $1 \%$ level of probability (Duncan's Multiple Rang Test). 
Table 5. Longevity (in days) and fecundity of predator C. undecimpunctata reared on two aphid species under controlled conditions.

\begin{tabular}{|c|c|c|c|c|c|c|c|}
\hline \multirow{2}{*}{$\begin{array}{c}\text { Aphid } \\
\text { species }\end{array}$} & \multicolumn{4}{|c|}{ Female longevity } & \multirow{2}{*}{ Male longevity } & \multicolumn{2}{c|}{ Female fecundity } \\
\cline { 2 - 8 } & Pre-oviposition & Oviposition & Post-oviposition & Total & & Total \\
\hline A. gossypii & $5.3 \pm 0.15 \mathrm{~b}$ & $33.7 \pm 1.18 \mathrm{~b}$ & $3.5 \pm 0.48 \mathrm{~b}$ & $42.5 \pm 1.0 \mathrm{~b}$ & $36.4 \pm 1.1 \mathrm{~b}$ & $4.77 \mathrm{~b}$ & $181.1 \pm 5.97 \mathrm{~b}$ \\
\hline H. pruni & $6.1 \pm 0.23 \mathrm{a}$ & $38.0 \pm 1.1 \mathrm{a}$ & $4.3 \pm 0.39 \mathrm{a}$ & $48.5 \pm 0.79 \mathrm{a}$ & $39.0 \pm 1.0 \mathrm{a}$ & $8.96 \mathrm{a}$ & $301.9 \pm 7.3 \mathrm{a}$ \\
\hline
\end{tabular}

Mean followed by the same letter in a column for each predator are not significantly different at the $1 \%$ level of probability (Duncan's Multiple Rang Test).

Table 6. Longevity (in days) and fecundity of predator Chrysoperla carnea adults when reared on different types of food under laboratory conditions $\left(27^{\circ} \mathrm{C} \& 65+5 \%\right.$ R.H. $)$.

\begin{tabular}{|c|c|c|c|c|c|c|c|}
\hline \multirow{2}{*}{$\begin{array}{c}\text { Aphid } \\
\text { species }\end{array}$} & \multicolumn{4}{|c|}{ Female longevity } & \multirow{2}{*}{ Male longevity } & \multicolumn{2}{c|}{ Female fecundity } \\
\cline { 2 - 7 } \cline { 6 - 7 } A. gossypii & Pre-oviposition & Oviposition & Post-oviposition & Total & & Total \\
\hline H. pruni & $7.0 \pm 0.73 \mathrm{~b}$ & $29.0 \pm 1.31 \mathrm{~b}$ & $5.28 \pm 0.36 \mathrm{a}$ & $39.28 \mathrm{~b}$ & $10.14 \pm 0.73 \mathrm{a}$ & $9.78 \mathrm{~b}$ & $327.73 \pm 31.19 \mathrm{~b}$ \\
\hline
\end{tabular}

Mean followed by the same letter in a column for each predator are not significantly different at the $1 \%$ level of probability (Duncan's Multiple Rang Test). 


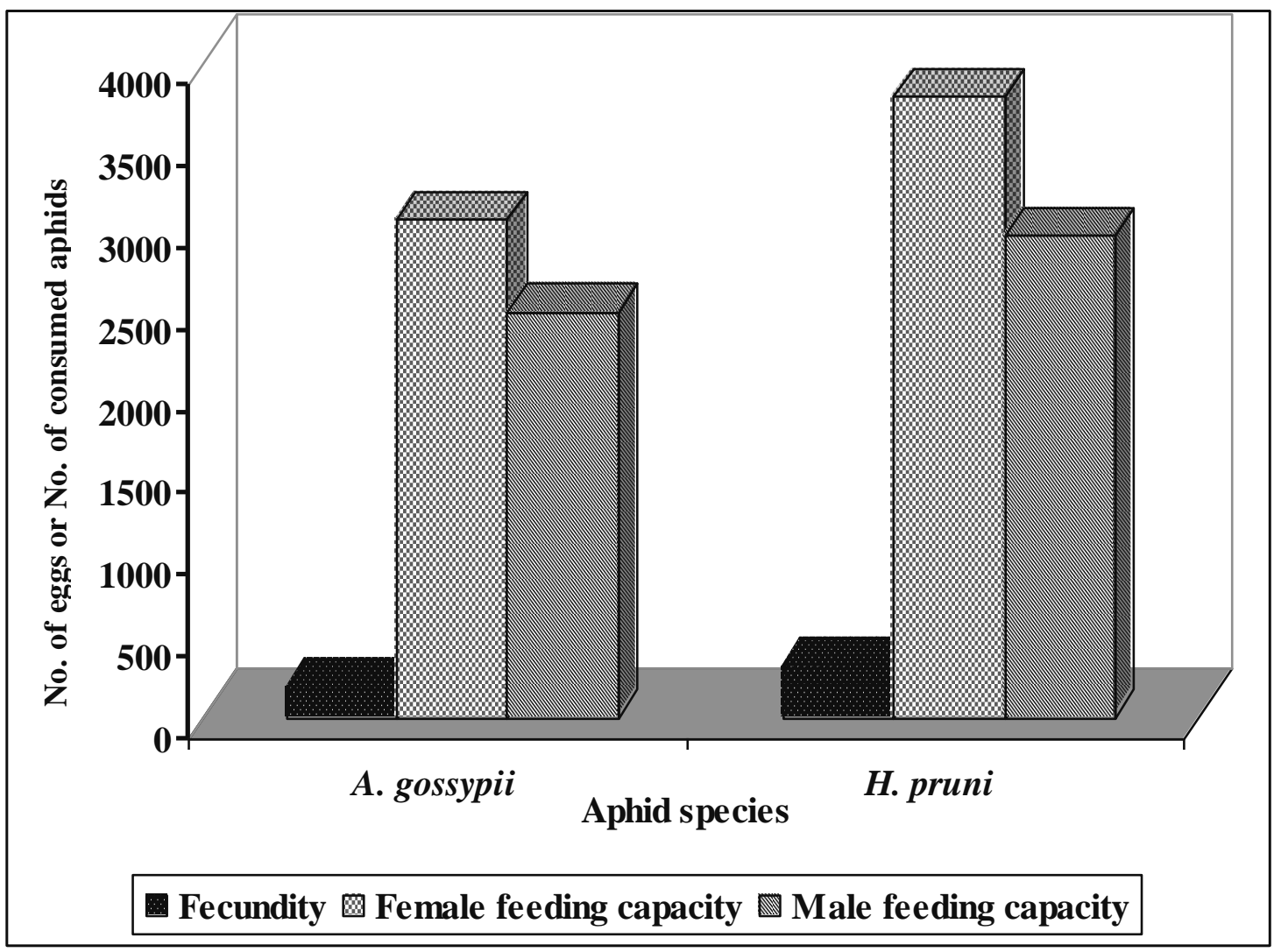

Fig. 1. Feeding capacity and fecundity of C. undecimpunctata adults reared on two aphid species under controlled conditions.

\section{REFERENCES}

1. Abou Zied, N.A., M.S. I. El-Dakroury, M.S.T. Abbas and A. H. El-Heneidy. 1978. Development and efficiency of Coccinella undecimpunctata Reiche as related to feeding on Heliothis armigera $\mathrm{Hb}$. (Coleoptera: Coccinellidae, Lepidoptera: Noctuidae). Agric. Res. Rev. 56: 37-39.

2. Abou-Bakr, H.E. 1989. Biocycle of Parachrysopa pallens (R.) as influenced by nourishment on two different preys (Neuroptera: Chrysopidae). Proc.Int. Cont. Econ. Entomol., Cairo, Dec. 11-24, Vol. $11: 25-31$.

3. Ali, Sh.A.M. 2008. Relationship between aphids and aphidophagous insects in ElKhattara district. Ph. D. Thesis, Fac. of Agric., Zagazig Univ., pp. 191.

4. Atlihan, R., M. S.Ozgokee and M. B. Kaydan. 2001. Some biological characteristics of Chrysoperla carnea (Stephens) (Neuroptera: Chrysopidae) on Hyalopterus pruni (Geoffer) (Homoptera: Aphididae). Turkiye Entomologi Dergisi. 25 (3): 223-230. 
5. Balasubramani, V. and M. Swamiappan. 1994. Development and feeding potential of the green lacewing Chrysoperla carnea Steph. (Neuroptera: Chrysopidae) on different insect pests of cotton. Anzeiger fuer Schaedlingskunde, Pflanzenschutz, Umweltschutz. 67 (8): 165-167.

6. Barakat, A.A.R. 2005. Effect of aphid species and its host plant on the feeding capacity of some aphidivorous insects. M. Sc. Thesis, Faculty of Agriculture, AlAzhar University,pp. 106.

7. CoHort Software. 2004. CoStat. www. CoHort com. Monterey, California, U.S.A.

8. El-Hag, E.A. and A.A. Zaitoon. 1996. Biological parameters for four coccinellid species in central Saudi Arabia. Bio. Control 7 : 316-319.

9. El-Maghraby, M.M.A., M.M. El-Zohairy, Aziza, M. El-Gantiry and Sh. A.M. Ali. 2008. Biological characteristics and predation efficacy of Chrysoperla carnea (Stephens) on certain preys associated with different host plants. Egypt. J. of Appl. Sci., 23 (10A): 374-387.

10. El-Maghraby, M.M.A. 1993. Seasonal abundance of the cruciferous aphid Brevicoryne brassicae L. (Homoptera, Aphididae) in relation to the primary and hyperparasitoids on cauliflower in Zagazig Region, Egypt. J. Agric. Res. 20 (5): 1627-1639.

11. Eraky, S.A. and M.A.K. Nasser. 1993. Effect of constant temperatures on Coccinella undecimpunctata L. (Coleoptera: Coccinellidae). Assiut J. Agric. Sci. 24,223-231.

12. Ghanim, A.A. and M. A. El-Adl. 1987. The feeding capacity and duration of the larval instars of three ladybird beetles fed on different aphid species under natural weather conditions at Mansoura. Egypt. J. Agric. Sci., Mansoura Univ., 12,981987.

13. Megahed, H. E.A. 2000. Studies on aphid . Ph. D. Thesis, Fac. of Agric., Zagazig Univ., pp. 206.

14. Mohammed, E.N. 1996. Studies on using certain native predators in the control of certain insect pest. M. Sc. Thesis, Faculty of Agriculture, Mansoura University , pp. 153.

15. Soares, A.O., R.B. Elias, R.Resendes and H. Figueiredo. 2003. Contribution to the knowledge of the coccinellidae (Cloeoptera) fauna from the Azores ispands. Arquipelago. Life and Marine Sciences 20A : 47-53.

16. Yuksel, S. and H. Goemen. 1992. The effectiveness of Chrysoperla carnea (Stephens) (Neuroptera, Chrysopidae) as apredator on cotton aphid Aphis gossypii Glov. (Homoptera, Aphididae). Proceeding of the second Turkish National Congress of Entomology 209-219. 
Aphis gossypii (Glover) الخصائص البيولوجية لمفترسين على من القطن

ومن البرقوق الدقيقى Hyalopterus pruni (Geoffroy) تحت الظروف المعملية

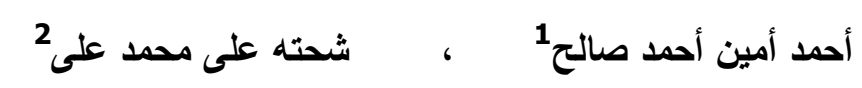

1. قسم بحوث الدكافحة البيولوجية - معهد بحوث وقاية النباتات - مركز البحوث الزراعية الدقى -

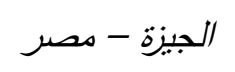

2. قسم بحوث الحشرات الثاقبة الداصة - معرة بحوث وقاية النباتات - مركز البحوث الزراعية الدقى

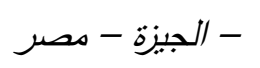

أجريت دراسات معملية لدراسة بعض الخصائص البيولوجية لنوعين من المفترسات هما أبوالعيد

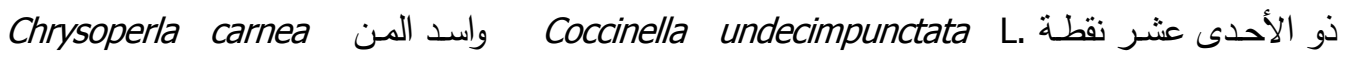
ومن البرقوق الدقيقى A. gossypii عند ترييتهما على من القطن (Stephens)

أوضحت النتائج أن فترة النمو من فقس البيض حتى خروج الحشرة الكاملة لفنترس أبو العيد

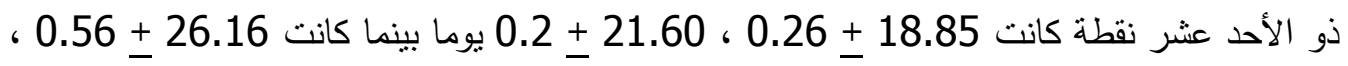

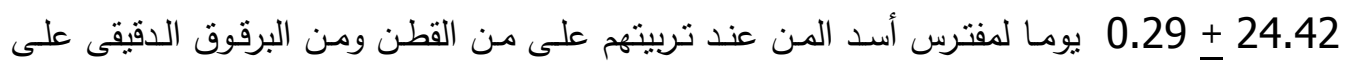

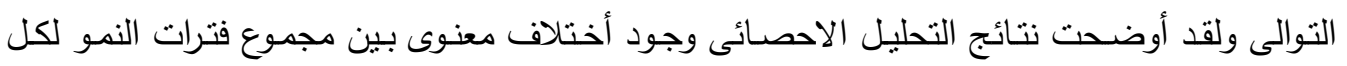

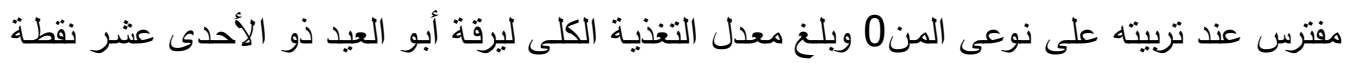

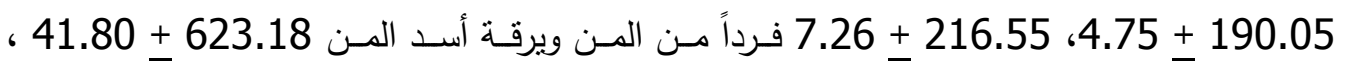

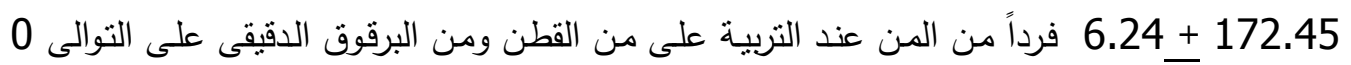

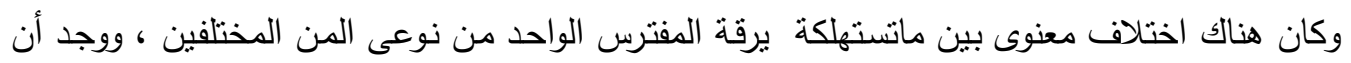

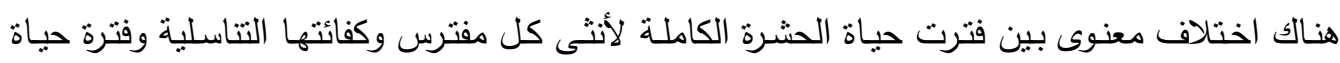

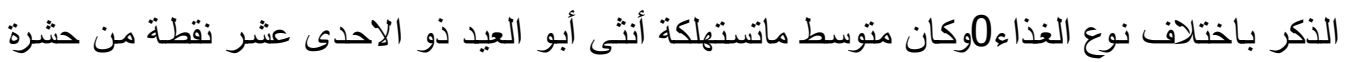

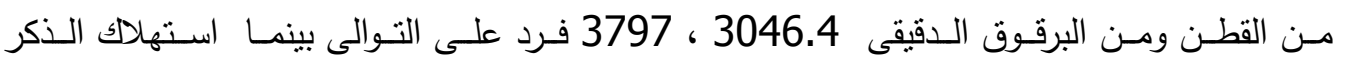

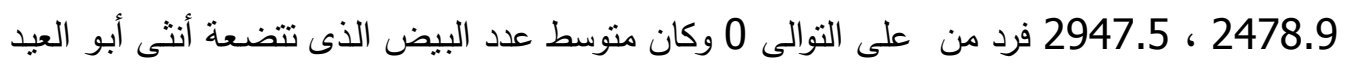

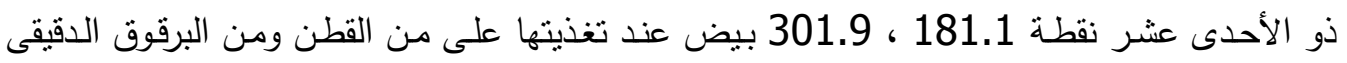

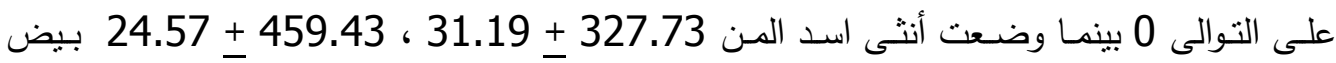

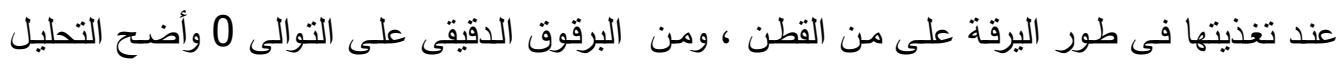

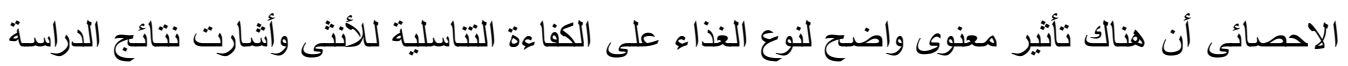

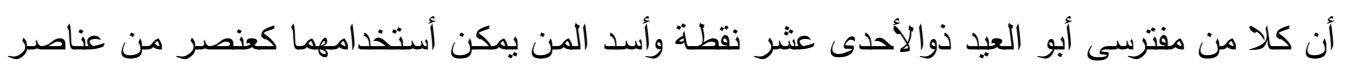
المكافحة الحيوية لدكافحة أنواع المن سابقة الذكر 0 